Nidhomul Haq Vol 3 No: 1 April 2018

ISSN 2503-1481

\title{
ANALISIS STANDAR PENDIDIK DAN TENAGA KEPENDIDIKAN (Studi di SDN 3 Tamanagung Banyuwangi)
}

\author{
Sudarsri Lestari \\ Dosen Institut Agama Islam Ibrahimy Banyuwangi \\ lilis@iaiibrahimy.ac.id
}

\begin{abstract}
Standards of educators and education personnel are one of the eight national standards of education. Standards of educators and educational personnel are the standards governing the qualifications that must be possessed by educators and education personnel, both academic and non academic qualifications. SDN 3 Tamanagung is one of the primary schools in Kabupaten Banyuwangi which has educators and education personnel 8 people. This study aims to analyze the implementation of standard educators and education personnel at SDN 3 Tamanagung Banyuwangi. The method used in this research is qualitative method with descriptive research type. Data collection methods used were interviews, observation, and documentation. Testing the validity of data is done by using triangulation. The result of the research found that the head of SDN 3 Tamanagung has fulfilled the general qualification and special qualification. For educators, there is one teacher SDN 3 Tamanagung who do not meet the minimum qualifications, which is still educated diploma. In non academic qualification, all educators and education personnel at SDN 3 Tamanagung have fulfilled various competency fields, which are pedagogic, personality, social, and professional competence.
\end{abstract}

Keywords: Educators, Education personnel, Standards

\section{A. PENDAHULUAN}

Mutu Pendidikan Nasional akan terukur lewat ketercapaian segenap Standar Pendidikan Nasional. Standar Nasional Pendidikan (SNP) diatur dalam Peraturan Pemerintah Nomor 32 Tahun 2013 tentang Standar Nasional Pendidikan meliputi standar isi, standar proses, standar kompetensi kelulusan, standar pendidik dan tenaga kependidikan, standar sarana dan prasarana, standar pengelolaan, standar pembiayaan dan standar penilaian pendidikan. Pada peraturan tersebut standar nasional pendidikan diartikan sebagai kriteria minimal tentang sistem pendidikan di seluruh wilayah hukum Negara Kesatuan Republik Indonesia, berfungsi sebagai dasar dalam perencanaan, pelaksanaan, dan pengawasan pendidikan dalam rangka mewujudkan pendidikan nasional yang bermutu.

Standar pendidik dan tenaga kependidikan merupakan standar yang mengatur kualifikasi yang harus dimiliki oleh pendidik dan tenaga kependidikan, baik kualifikasi akademis maupun non akademis. Berdasarkan Undang-Undang No. 19 Tahun 2005, dijelaskan bahwa: "Standar pendidik dan tenaga kependidikan adalah kriteria pendidikan prajabatan dan kelayakan fisik maupun mental, serta pendidikan dalam jabatan." Artinya standar itu meliputi sejumlah kriteria yang harus dipenuhi sebelum dan setelah menjalani jabatan sebagai pendidik dan tenaga kependidikan.

Berdasarkan Undang-Undang No.19

Tahun 2005, Guru adalah pendidik profesional dengan tugas utama mendidik, mengajar, membimbing, mengarahkan, melatih, menilai, dan mengevaluasi peserta didik pada pendidikan anak usia dini jalur pendidikan formal, pendidikan dasar, dan pendidikan menengah. Dalam hal ini, Profesional merupakan suatu pekerjaan atau kegiatan yang dilakukan oleh seseorang dan menjadi sumber penghasilan kehidupan yang memerlukan keahlian, kemahiran, atau kecakapan yang memenuhi standar mutu atau 
norma tertentu serta memerlukan pendidikan profesi. Sebagai pendidik yang professional, setiap guru wajib memenuhi standar kualifikasi akademik dan kompetensi guru yang berlaku secara nasional dan memiliki sertifikat pendidik.

Pada lampiran UndangUndang No.16 Tahun 2007, dijelaskan bahwa guru sebagai tenaga pendidik harus memiliki kualifikasi akademik pendidikan minimum diploma empat (D-IV) atau sarjana (S1) dalam bidang pendidikan SD/MI (D-IV/S1 PGSD/PGMI) atau psikologi yang diperoleh dari program studi yang terakreditasi. Sedangkan standar kompetensi yang harus dimiliki guru meliputi kompetensi pedagogik, kepribadian, sosial, dan profesional.

Tenaga kependidikan adalah anggota masyarakat yang mengabdikan diri dan diangkat untuk menunjang penyelenggaraan pendidikan. Tenaga kependidikan meliputi kepala sekolah/madrasah, pengawas satuan pendidikan, tenaga administrasi, tenaga perpustakaan, tenaga laboratorium, teknisi, pengelola kelompok belajar, pamong belajar, dan tenaga kebersihan (Badan Standar Nasional Pendidikan).

Setiap sekolah/madrasah wajib mengikuti standar pendidikan yang telah ditetapkan secara nasional. Hal ini guna menjamin mutu pendidikan di Indonesia. SDN 3 Tamanagung merupakan salah satu sekolah dasar negeri yang terdapat di kecamatan Cluring kabupaten Banyuwangi. Sebagai salah satu penyelenggara kegiatan pendidikan, SDN 3 Tamanagung tentu juga turut serta mensukseskan tercapainya delapan standar nasional pendidikan, yang salah satu diantaranya adalah standar pendidik dan tenaga kependidikan. Penelitian ini bertujuan untuk menganalisis terkait pelaksanaan standar pendidik dan tenaga kependidikan di SDN 3 Tamanagung Banyuwangi.

\section{B. HASIL DAN PEMBAHASAN}

SDN 3 Tamanagung merupakan salah satu Sekolah dasar Negeri yang ada di Kecamatan Cluring Kabupaten Banyuwangi. Sekolah ini memiliki 6 rombongan belajar. Adapun data pendidik dan tenaga kependidikan di sekolah tersebut dapat dilihat pada tabel di bawah ini.
Tabel Data Pendidik dan Tenaga Kependidikan SDN 3 Tamanagung

\begin{tabular}{|c|c|c|c|c|c|c|}
\hline \multirow{2}{*}{ No } & \multirow{2}{*}{$\begin{array}{c}\text { Jabatan } \\
\text { dalam } \\
\text { Tugas }\end{array}$} & \multicolumn{2}{|c|}{$\begin{array}{c}\text { Jenis } \\
\text { Kelamin }\end{array}$} & \multirow{2}{*}{$\begin{array}{c}\text { Statu } \\
\mathrm{S}\end{array}$} & \multirow{2}{*}{$\begin{array}{l}\text { Pendidi } \\
\text { kan } \\
\text { Terakhi } \\
\text { r } \\
\end{array}$} & \multirow{2}{*}{$\begin{array}{l}\text { Sertifikat } \\
\text { Pendidik }\end{array}$} \\
\hline & & $\mathrm{L}$ & $\mathrm{P}$ & & & \\
\hline 1 & $\begin{array}{l}\text { Kepala } \\
\text { Sekolah }\end{array}$ & 1 & - & PNS & $\mathrm{S} 1$ & Ada \\
\hline 2 & $\begin{array}{l}\text { Guru Kelas } \\
\text { VI }\end{array}$ & 1 & - & PNS & $\mathrm{S} 1$ & Ada \\
\hline 3 & $\begin{array}{l}\text { Guru Kelas } \\
\text { V }\end{array}$ & - & 1 & $\begin{array}{l}\text { Non } \\
\text { PNS }\end{array}$ & D2 & Tidak \\
\hline 4 & $\begin{array}{l}\text { Guru Kelas } \\
\text { IV }\end{array}$ & - & 1 & PNS & $\mathrm{S} 1$ & Ada \\
\hline 5 & $\begin{array}{l}\text { Guru Kelas } \\
\text { III }\end{array}$ & 1 & - & PNS & S1 & Ada \\
\hline 6 & $\begin{array}{l}\text { Guru Kelas } \\
\text { II }\end{array}$ & - & 1 & PNS & $\mathrm{S} 1$ & Ada \\
\hline 7 & $\begin{array}{l}\text { Guru Kelas } \\
\text { I }\end{array}$ & - & 1 & $\begin{array}{l}\text { Non } \\
\text { PNS } \\
\end{array}$ & $\mathrm{S} 1$ & Tidak \\
\hline 8 & $\begin{array}{l}\text { Guru } \\
\text { Mapel/ } \\
\text { Operator }\end{array}$ & - & 1 & $\begin{array}{l}\text { Non } \\
\text { PNS }\end{array}$ & $\mathrm{S} 1$ & Tidak \\
\hline
\end{tabular}

Berdasarkan data tersebut diketahui bahwa pendidik dan tenaga kependidikan di SDN 3 Tamanagung berjumlah 8 orang, yang terdiri dari kepala sekolah, 7 guru kelas, dan 1 guru mata pelajaran yang merangkap sebagai operator sekolah. Di SDN 3 Tamanagung memiliki 7 tenaga pendidik, 4 pendidik berstatus pegawai negeri sipil, dan sisanya 3 pendidik berstatus non pegawai negeri sipil, sedangkan kepala sekolah berstatus pegawai negeri sipil.

Pada lampiran Permendiknas No.13 Tahun 2007, menjelaskan bahwa kualifikasi kepala sekolah terdiri dari kualifikasi umum dan kualifikasi khusus. Kualifikasi umum yang harus dimiliki meliputi: (a) memiliki kualifikasi akademik sarjana (S1) atau diploma empat (DIV) kependidikan atau nonkependidikan pada perguruan tinggi yang terakreditasi; (b) pada waktu diangkat sebagai kepala sekolah berusia setinggi-tingginya 56 tahun; (c) memiliki pengalaman mengajar sekurang-kurangnya 5 (lima) tahun menurut jenjang sekolah masing-masing; dan (d) memiliki pangkat serendah-rendahnya III/c bagi pegawai negeri sipil (PNS) dan bagi nonPNS disetarakan dengan kepangkatan yang dikeluarkan oleh yayasan atau lembaga yang berwenang. Sedangkan untuk kualifikasi khusus dijelaskan bahwa kepala SD/MI harus memenuhi kualifikasi: (a) berstatus sebagai 
guru SD/MI; (b) Memiliki sertifikat pendidik sebagai guru SD/MI; dan (c) Memiliki sertifikat kepala SD/MI yang diterbitkan oleh lembaga yang ditetapkan Pemerintah.

Berdasarkan hasil wawancara, observasi, dan dokumentasi, diperoleh data bahwa kepala SDN 3 Tamanagung telah memenuhi kualifikasi umum sebagai Kepala Sekolah, yaitu: (a) pendidikan terakhir adalah S1 pada jurusan kependidikan pada kampus yang telah terakreditasi; (b) pada saat diangkat sebagai kepala sekolah berusia 52 tahun, hal tersebut telah memenuhi syarat kualifikasi bahwa kepala sekolah/madrasah pada waktu diangkat maksimal berusia 56 tahun; dan (c) pada saat diangkat sebagai kepala sekolah telah memiliki pengalaman mengajar selama 27 tahun pada jenjang Sekolah Dasar. Pada kualifikasi khusus, kepala SDN 3 Tamanagung juga telah memenuhi seluruh kualifikasi, yang meliputi: (a) telah berstatus sebagai guru SD/MI; (b) telah memiliki sertifikat pendidik yang diterbitkan oleh Lembaga Pendidikan Tenaga Kependidikan (LPTK) penyelenggara; dan (c) telah memiliki sertifikat kepala SD yang diterbitkan oleh Lembaga pendidikan dan Pelatihan calon Kepala Sekolah (LPPSK).

Selain telah memenuhi kualifikasi umum dan kualifikasi khusus, kepala SDN 3 Tamanagung juga telam memenuhi kompetensi yang disyaratkan oleh Permendiknas No. 13 Tahun 2007. Adapun dimensi kompetensi yang telah terpenuhi meliputi: (a) kepribadian, misalnya bersikap terbuka dan mampu mengendalikan diri dan menemukan solusi dalam pemecahan masalah; (b) manajerial, misalnya menyusun perencanaan, mengoptimalkan sumber daya yang terdapat di sekolah maupun lingkungan sekitarnya, mengelola guru secara optimal, menciptakan iklim yang kondusif di sekolah, serta melakukan kerjasama dengan pihak lain; (c) kewirausahaan, misalnya memiliki naluri kewirausahaan dengan mendayagunakan lahan kosong di lingkungan sekolah dengan menanam berbagai tanaman yang dapat dimanfaatkan dan membawa keuntungan bagi sekolah, ; (d) supervisi, misalnya merancang, melaksanakan, dan menindaklanjuti supervisi akademik terhadap guru guna peningkatan profesionalisme guru; dan (e) sosial, misalnya dengan bekerjasama Bersama pihak lain, serta turut berpartisipasi dalam berbagai kegiatan masyarakat sekitar sekolah.

Berdasarkan tabel data pendidik dan tenaga kependidikan, diperoleh data bahwa salah satu guru di SDN 3 Tamanagung masih berpendidikan D2 (Diploma 2). Hal tersebut tidak memenuhi kualifikasi pendidik, sebab berdasarkan lampiran Permendiknas No.16 Tahun 2007, menyebutkan bahwa Guru pada SD/MI, atau bentuk lain yang sederajat, harus memiliki kualifikasi akademik pendidikan minimum diploma empat (D-IV) atau sarjana (S1) dalam bidang pendidikan SD/MI (DIV/S1 PGSD/PGMI) atau psikologi yang diperoleh dari program studi yang terakreditasi.

Guru yang tidak memenuhi kualifikasi akademik di SDN 3 Tamanagung adalah guru kelas V. Berdasarkan hasil wawancara dengan guru tersebut, menjelaskan bahwa saat ini tengah mengenyam pendidikan di salah satu kampus swasta di Banyuwangi guna memperoleh gelar sarjana pendidikan. Hal ini bertujuan agar dirinya mampu memenuhi kualifikasi minimum yang disyaratkan oleh badan standar nasional pendidikan. Selain ditemukan fakta tentang kualifikasi akademik, dalam tabel data pendidik dan tenaga kependidikan juga terdapat 3 guru yang belum memiliki sertifikat pendidik. Sertifikat pendidik adalah bukti formal sebagai pengakuan yang diberikan kepada guru dan dosen sebagai tenaga profesional (UndangUndang No.14 Tahun 2005). Jika mengacu pada aturan perundangundangan tersebut, maka dapat dikatakan bahwa guru yang belum memiliki sertifikat pendidik masih belum profesional.

Selain kualifikasi akademik, tenaga pendidik juga diwajibkan memiliki kualifikasi non akademik, yakni memenuhi empat standar kompetensi utama guru yang mencakup kompetensi pedagogik, kepribadian, sosial, dan profesional. Berdasarkan hasil wawancara, observasi, dan dokumentasi, diperoleh hasil bahwa guru di SDN 3 Tamanagung telah memenuhi kompetensi sebagai guru SD. Pada kompetensi pedagogik, guru telah melaksanakan beberapa hal, misalnya: (a) mengembangkan kurikulum terkait bidang yang diampu, hal tersebut ditunjukkan dengan dimilikinya seperangkat perencanaan 
pembelajaran pada kelas yang diampu; (b) berkomunikasi secara efektif, empatik, dan santun, hal tersebut ditunjukkan dengan saling menyapa antara guru dan siswa baik di dalam maupun di luar sekolah, selain itu ketika pembelajaran guru juga selalu memberikan pertanyaan dan tugas, serta memberikan respons atas pertanyaan maupun pernyataan yang dilontarkan siswa; serta (c) melaksanakan penilaian dan evaluasi proses dan hasil belajar.

Pada kompetensi kepribadian guru juga banyak melaksanakan beberapa hal, diantaranya: (a) menjadi teladan yang baik; (b) saling menghargai, baik terhadap sesame pendidik maupun peserta didik; (c) menunjukkan etos kerja dan tanggung jawab; serta (d) menjunjung kode etik profesi. Adapun pada kompetensi sosial diwujudkan melalui: (a) bersikap objektif dan tidak diskriminatif, baik terhadap sejawat maupun peserta didik; (b) berkomunikasi dengan baik kepada sesame pendidik, peserta didik, wali murid, maupun masyarakat; (c) mengikutsertakan wali murid dan masyarakat dalam program maupun penanganan kesulitan belajar; serta (d) berkomunikasi dengan rekan sejawat serta profesi lain.

Pada kompetensi professional, guru telah melaksanakan beberapa hal, misalnya: (a) Menguasai materi, struktur, konsep, dan pola pikir keilmuan yang mendukung mata pelajaran yang diampu; (b) menguasai standar kompetensi dan kompetensi dasar dari berbagai mata pelajaran pad akelas yang diampu; (c) memilih dan mengolah materi yang sesuai; dan (d) memanfaatkan teknologi informasi dan komunikasi untuk berkomunikasi dan mengembangkan diri.

Di SDN 3 Tamanagung ini terdapat seorang operator sekolah yang juga merangkap sebagai guru mata pelajaran Bahasa Inggris. Kendati demikian, masih ada tenaga pendidik yang tidak dimiliki oleh sekolah ini, yakni guru pendidikan agama dan guru olahraga. Sementara ini, kedua bidang mata pelajaran tersebut diampu oleh guru yang berstatus pegawai negeri sipil dari sekolah lain.

\section{KESIMPULAN}

Berdasarkan hasil penelitian ini, dapat diperoleh kesimpulan bahwa: a) SDN Tamanagung memiliki 8 personel pendidik dan tenaga kependidikan

b) Kepala SDN 3 Tamanagung telah memenuhi kualifikasi umum dan kualifikasi khusus yang disyaratkan oleh perundang-undangan yang berlaku

c) Tenaga kependidikan di SDN 3 Tamanagung berjumlah 7 orang, yang terdiri dari 6 guru kelas dan 1 guru mata pelajaran yang merangkap sebagai operator sekolah.

d) Terdapat 1 tenaga pendidik yang belum memenuhi kualifikasi akademik, yakni masih berpendidikan D2

e) Seluruh tenaga kependidikan telah memnuhi kualifikasin non akademik, yang ditunjukkan dengan terlaksananya 4 kopetensi guru, yakni kompetensi pedagogis, kompetensi kepribadian, kompetensi sosial, dan kompetensi profesional. 
Nidhomul Haq Vol 3 No: 1 April 2018

ISSN 2503-1481

\section{DAFTAR PUSTAKA}

Badan Standar Nasional Pendidikan. 2018. Standar Pendidik dan Tenaga Kependidikan. Jaringan Dokumentasi dan Informasi Hukum. (online), http://bsnpindonesia.org/standar-pendidikan -dan-tenaga-kependidikan, (diakses 20 Februari 2018)

Khumaidi. 2013. Tenaga Kependidikan dalam Sistem Pendidikan Nasional (Analisis: Aspek Sumber Daya Pendidikan). Jurnal Pendidikan. Vol. 4 Tahun 2013 download. portalgaruda.org/article.php? (diakses 20 Februari 2018)

Miles, M.B. \& Huberman, A.M. 1992. Analisis Data Kualitatif. Terjemahan Rohidi, T.R. 2014. Jakarta: Penerbit Universitas Indonesia (UI-Press)

Moleong, L.J. 2007. Metodologi Penelitian Kualitatif. Bandung: PT Remaja Rosdakarya

Peraturan Pemerintah Nomor 32 Tahun 2013 Tentang Perubahan Atas Peraturan Pemerintah Nomor 19 Tahun 2005 Tentang Standar Nasional Pendidikan. Jaringan Dokumentasi dan Informasi. (Online), kelembagaan.ristekdikti.go.id/wp-content/uploads /2016/08/PP0322013.pdf, (diakses 20 Desember 2017)

Peraturan Menteri Pendidikan Nasional Nomor 13 Tahun 2007 tentang Standar Kepala Sekolah/Madrasah. Jaringan Dokumentasi dan Informasi. (online), Dokumentasi dan Informasi. (online), simpuh.kemenag.go.id/regulasi/ permendiknas_13_07.pdf, (diakses 20 januari 2018)

Peraturan Menteri Pendidikan Nasional Nomor 16 Tahun 2007 tentang Kualifikasi Akademik dan Kompetensi Guru. Jaringan Dokumentasi dan Informasi. (online), vervalsp.data.

kemdikbud.go.id/.../Permendiknas\%20No\%2016\%20Tahun\%202007.pdf, (diakses 20 januari 2018)

Undang-undang RI Nomor 14 Tahun 2005 tentang Guru dan Dosen. Jaringan Dokumentasi dan Informasi. (online), www.mahkamahkonstitusi. go.id, (diakses 30 Oktober 2013) 